\title{
Individual heat metering and charging of multi-dwelling residential housing
}

\author{
Simon Siggelsten \\ Malmö University, Malmö, Sweden, and \\ Stefan Olander \\ Construction Management, Lund University, Lund, Sweden
}

\section{Individual heat metering}

\begin{abstract}
Purpose - The purpose of this paper is to look more closely at the residents' attitude to individual heat metering and charging systems (IMC) of multi-family dwellings in residential properties, and to evaluate the tenant's perception of IMC and how it may affect the continued expansion of such systems.

Design/methodology/approach - The research in this paper is based on a questionnaire and interviews with tenants at two municipal housing companies, in Sweden, that currently are using IMC. Findings - The studies in this paper show certain dissatisfaction with the applied IMC systems. This depends partly on the tenant's perceived lack of knowledge and partly because of the technical shortcomings of the IMC system.

Originality/value - In order to increase the extension of IMC a better understanding is required of how the systems work and why they are used. Information to the tenants needs to be improved and techniques need to be developed to create fairer systems of IMC and thus increase the level of acceptance from both landlords and tenants.
\end{abstract}

Keywords Heat measurement, Residential property, Tenancy, Sweden

Paper type Research paper

\section{Introduction}

All Member States of the European Union are committed to present national action plans for energy end-use efficiency and energy services in accordance with Directive 2006/32/EC (Directive 2006/32/EC, 2006). The action plans will be presented on three occasions during the period 2007-2016. The EC Directive is aimed at any energy consumption within the Community, but since the residential sector accounts for 41 per cent of energy used in Europe (JRC, 2008) any energy efficiencies made in the residential sector are of great importance. There are several eligible measures to improve the energy efficiency of properties in the residential sector such as additional insulation (wall cavities and roof); change to energy efficient windows (double/triple glazing) and efficient heating systems. However, occupants also affect a large proportion of the total energy consumption of residential properties.

Increased environmental awareness, locally and globally, has given much attention to the techniques and strategies of reducing energy use. A tool for working with the residents (end user) to reduce energy use in housing may be individual metering and charging (IMC) of heat and water. IMC is a technique and strategy to get the individual residents of the property to use less water and heat, thus achieving a reduction in total energy use of the property at hand. Surveys made in Germany and Sweden show an

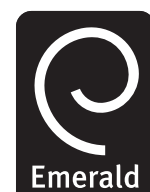

Structural Survey Vol. 28 No. 3,2010 pp. $207-214$ (C) Emerald Group Publishing Limited 0263-080X 
SS

28,3

208

average reduction of the heat consumption of approximately 10-20 per cent and a 15-30 per cent reduction with hot water (Berndtsson, 2003).

Most countries in Europe apply individual metering of water and heating. However, only a handful of them prescribe it for multi-dwelling residential property. For example in Germany it is fixed by law since 1981 (Bundesministeriums der Justiz, 1981), and in Denmark it is prescribed since 1997 for new residential buildings and since 1999 for existing ones (Boligministeriet, 1995). In Sweden there is no regulation in the law and only about 1 per cent of the dwellings have IMC (The National Board of Housing, Building and Planning, 2008, p.7). A possible reason for not having IMC might be the economic aspects. But a contributing factor may also be the residents' attitude to IMC, which this paper looks more closely at. The purpose of the research presented is to evaluate how tenants in multi-family dwellings perceive IMC and how it may affect the continued expansion of IMC in residential properties.

\section{The technology of individual metering and charging (IMC)}

The principal concepts behind IMC are that the tenants in multi-dwelling residential properties only pay for heat used individually, and by changing their behaviour achieving an overall decrease of energy usage. But for a tenant to save energy or money he or she must first be aware of the actual consumption and cost (Schou, 1982). Henryson et al. (2000) demonstrate the possibility to cut energy consumption using only information. IMC is a useful tool to create an opportunity for control and awareness of the size of the individual cost of heat and water. All tenants in a property will not lower their consumption, but surveys made in Germany and Sweden show an average reduction of the heat consumption of approximately 10-20 per cent (Berndtsson, 2003). But a prerequisite for a given technology to work in the appropriate manner is that the users understand how it works (Layton, 1977).

It is relatively easy to individually measure the electricity used with an individual electricity meter, as the registered energy is equal to the energy delivered via the cables, with a small margin of error of the meter (Directive 2004/22/EC, 2004). It is also relatively easy to measure cold and hot water with a flow meter mounted on the water piping to each individual flat (ibid). Individual metering of heat is more complicated, although there are accurate gauges for measuring heat. Adjacent flats can influence each other and heat leaks between them (Andersson, 2001; Jensen, 1999). The different locations of the flats in the property also create different factors for the need of heating. Factors such as floor, point of the compass, exposure of wind and differences in housing envelope etc. create these different conditions (Kenworthy, 1978). External heat sources such as solar radiation, tea lights and candles, computers, TVs and cooking can also influence the metering system. Therefore, the basic idea of payment for heat actually used is really quite demanding.

Today, three main approaches to individual metering and charging of heat in residential properties are normally used (The National Board of Housing, Building and Planning, 2008, p. 32).

(1) flow metering, where flow and temperature of the water circulated in the radiator system is measured;

(2) radiator metering, where sensors installed on the radiators of the flat measure the emitted heat; and 
(3) temperature metering, where temperature sensors register the actual temperatures of certain locations of the flat.

Individual heat metering

A fourth option is individual heating, where each flat is equipped with its own boiler and thus all are paying for themselves. Individual heating can be appropriate in smaller housing with no common spaces suitable for the installation of a common heating system. Multi-dwelling housings with condominiums can also benefit if the common spaces and equipment required can be reduced.

Flow and radiator metering are similar to each other. Both systems measure the actual energy of heat added to the specific flat. An advantage with these two systems as well as with the individual heating is that the external sources of heat, such as solar radiation, candles, TV, computer and cooking, decrease the costs (Berndtsson, 1999). Another advantage is that window ventilation only increases the cost of heat for the individual who vents (Berndtsson, 1999). The amount of heat transported between the adjacent flats depends on the insulation capacity of the shared wall. Under certain circumstances, up to 95 per cent of the heat requirement for a flat can be received from the neighbour's via heat transport (Andersson, 2001), which is often considered as a major disadvantage of the system. An additional disadvantage are local deficiencies of the building envelope influencing higher costs of heat for the tenant and not the landlord. This also reduces the incentives for the landlord to deal with the deficiencies of the building envelope (Berndtsson, 1999). However this situation is different with condominium dwellings since the residents are also the owners of the property.

Temperature metering measures only the temperature at certain chosen locations in the flat. These temperatures determine the charging for the heat. Temperature metering is not influenced by transport of heat between flats, i.e. received heat from the neighbours. However, transport of heat between adjacent flats can lead to difficulties in maintaining the desired temperature. A tenant desiring 18 degrees (Celsius) living next to a tenant desiring 23 degrees can result in significant transport of heat between the flats, depending on the insulation ability of the shared wall (Andersson, 2001). Also depending on the heat capacity of the radiators, the colder flat will be warmer than 18 degrees and the warmer flat will be colder than 23 degrees, leading to a potential conflict. In contrast to metering of the added heat, external sources of heat will not decrease the cost of heat, but temporarily instead increase the temperature and thus indirectly also the cost of heat (Berndtsson, 1999). However, an eventual local deficiency of the building envelope does not increase the individual's cost of heat and the incentives remain for the landlord to attend to the shortcomings (Berndtsson, 1999).

The system for temperature metering is not active if the outdoor temperature rises beyond a certain level, for the reason of not having external heat influences of the metering. There are further advantages and disadvantages with the IMC systems respectively which are not included in this paper (Berndtsson, 1999; The National Board of Housing, Building and Planning, 2008).

\section{Methodology and objective}

Berndtsson (1999) demonstrates several shortcomings with today's measuring techniques available for individual heat metering. These and additional imperfections are also indicated in a report by The National Board of Housing, Building and Planning (2008). They are also investigating whether the individual 
SS

28,3

210 metering of water and heat are economically profitable or not for the landlords (The National Board of Housing, Building and Planning, 2008). However, limited research exists of how the tenants perceive the metering and how they are affected by shortcomings of current metering techniques (The National Board of Housing, Building and Planning, 2008).

An investigation has been carried out with the intention to explore how tenants perceive and are affected by individual metering of the heat in their flats. In total, 80 interviews were carried out of a total of 113 tenants in Eslöv, Sweden (Case A) with a response rate of 71 per cent. Four tenants did not want to participate in the study for various reasons and the remaining 29 were not home during the three days the interviews were conducted. Each interview was conducted at the home of the tenant. The duration of the interview varied between five minutes and one hour depending on the tenant's interest in the questions. The average interview lasted approximately 15 minutes. A questionnaire was also sent to 1,800 tenants in Helsingborg, Sweden (Case B) with 692 respondents. The response rate for case B is low (38 per cent) and it may be due to several factors. There is a possibility that only those who are discontented answered, or the contrary. However, a comparison between questionnaire responses (case B) and interviews (case A), where the percentage of answers only depended on who was at home or not, demonstrated equivalent answers. This argues against the theory that only one category of tenants have responded. The interviews were carried out in October 2008 and the questionnaire was sent out in November 2008. Landlord A has made use of IMC since 2005 and landlord B since 1997. Both are municipal housing companies.

In Sweden, where the investigation was conducted, IMC is installed in approximately 1 per cent of the total of 2.4 million flats (The National Board of Housing, Building and Planning, 2008), mainly by the municipal housing companies. There has been an increase of installations in Sweden in recent years because of increased environmental awareness and the development of less expensive and better components.

\section{The individual metering and charging system of the investigated cases}

In both cases, the landlords use temperature metering as an individual metering and charging system. Temperature sensors are mounted in all rooms of the flat except the hall, kitchen and bathroom. The reason that no sensor is mounted in the kitchen is that activities such as cooking should affect the temperature metering as little as possible. The idea is the same for the bathroom, i.e. that neither bathing nor showering will influence temperature. Metering is not carried out during the summer when the solar radiation has a big impact on the temperature. Other factors that may affect the metering unfavourably are for example the number of people living in the flat and the amount of electrical appliances used. An individual emits approximately $100 \mathrm{~W}$ of thermal energy at rest and 400-500W when tidying. The use of household electricity varies widely from case to case, but a study made in Sweden shows an average use of $22 \mathrm{kWh}$ per $\mathrm{m}^{2}$ and year (Elforsk, 2008). In theory, this means that the tenants must pay for the energy twice, first the electricity consumed and then for the heat emitted. With malicious ventilation, the tenant is not affected by higher heating costs, but instead it will be cooler in the flat resulting in lower costs. Examples of the benefits of temperature metering are that there is no incentive for tenants to manipulate the ventilation and in that way reduce the heat flow from the flat. It is also not possible to "steal heat" from neighbours by heat transport through the adjacent walls, ceilings and 
floors. The injustice of having a flat in an appropriate location of the housing, e.g. on a gable wall, disappears.

\section{Findings}

Since both cases indicated equivalent responses some results are a combination of both cases and where the answers differ they are presented individually. In case A, it is almost equal between those who perceive the metering as fair, 43 per cent, and unfair, 45 per cent, whereas slightly less than half of the respondents of case B, 47 per cent, believe that the individual metering are fair, 32 per cent perceive the metering as unfair and 21 per cent have no opinion. At the same time, 64 per cent in both surveys feel that they have received little or no information about how the metering works. There is a small connection between the questions; those who feel they have received little or no information also perceive the metering as unfair to a slightly larger extent (Pearson correlation 0.3). The understanding of the information is not so great among the respondents, 44 per cent believe they have understood nothing or just a bit of the information they received. The interviews in case A show a widespread misunderstanding of how the metering technically operates. The complexity of the metering makes it difficult for a tenant to understand how things fit together. The landlord of case A admits problems with tenants who complain about the IMC system. The landlord of case B admits no such problems.

All respondents were asked if they wanted to have a metering system for the heat when they moved into their flat; or when the system was installed if they already lived in the flat in question. Only 23 per cent desired a metering system for the heat at that time, 40 per cent did not desire it and 37 per cent had no opinion on the matter. Today, the view looks a little different, 70 per cent want some form of heat metering, while 18 per cent want everyone to pay the same amount for heating. A total 34 per cent of all respondents say they have been affected by the metering and have now deliberately a lower indoor temperature in their flats.

Three of the 80 respondents in case A were totally against individual metering and charging for ideological reasons. They based their opinions on the people who live in the same housing belonging to some form of joint collective and therefore they should also equally share the costs related to the property. So if someone used little heat or water, it should be a benefit for all tenants, and if a family has a greater need for heat or water they should be supported by spreading the cost over all the residents.

A local tenants' association of the housing in case A is strongly engaged on the IMC issue and is demanding changes to the metering and charging system.

\section{Discussion}

The possibility of reduced energy use in multi-dwelling housings with IMC has already been demonstrated (The National Board of Housing, Building and Planning, 2006), but a reduction in energy use does not necessarily mean a lower overall cost. Economic profitability of individual metering and charging systems depends on others factors such as installation and operating costs (The National Board of Housing, Building and Planning, 2008). The studies in this paper show certain dissatisfaction with the applied IMC systems. This is based partly on the tenant's perceived lack of knowledge but also because of the technical shortcomings of the IMC system. Attitudes can affect the operation of an IMC system and dissatisfied tenants also require additional resources from the property owner's side.

\section{Individual heat} metering

\section{1}


SS

28,3

212

Technology and sociology are separate things that obviously can be combined. For a technique to meet its objective, it should also be used appropriately. A technique can be simple and obvious and the user understands how the technique is meant to be used. Or a technique can be so complex and instruction and training may be necessary for users to understand. It is of great importance to study people's reactions, together with the new technology. Using a device without studying how it is used provides limitations in function and development of the product. As Layton wrote: "What is needed is an understanding of technology from inside, both as a body of knowledge and as a social system. Instead, technology is often treated as a 'black box' whose contents and behaviour may be assumed to be common knowledge” (Layton, 1977, p. 198).

The results of the interviews indicate that many are annoyed with the system of individual metering and charging, but also that many have misunderstood how the system works. While many are annoyed at the IMC system, a majority of tenants perceive that they have received limited information from the landlord about how the system works. The fact that 21 per cent of the respondents of the investigation have no opinion whether the IMC system is fair or not, shows the difficulty in understanding the technique. As the technique advances, a great responsibility falls on the landlord to inform tenants so that the system is used in the way it is meant to with the best possible results. The only thing tenants can see are small white boxes with a wire coming out and disappearing into a wall. They do not see the chain of circumstances affecting the metering results and in turn their heating costs.

Increased efforts to reach out to all concerned with information about the IMC provides a temporary increase in cost but can also result in a reduction in operating costs if the consequence is that the IMC system is used properly and tenant dissatisfaction is reduced. A correctly used IMC system is a precondition for achieving the objectives of the IMC, i.e. reduction in energy use and a fair distribution of heating costs. The difference in the number who perceive it as unfair in case A compared with case B, may depend on the tenants' association engagement in the issue for case A. This shows the importance of involving the tenants from the beginning to avoid conflicts.

It is not only necessary with information to understand how heat metering systems function, but information should also be provided on how tenants can save heat energy. A Swedish study shows the possibility of lowering the consumption of electricity by having only information (Henryson et al., 2000). By studying the habits of the tenants and informing them about electricity saving opportunities, the consumption was reduced in some cases by up to 10 per cent. Examples of measures to save heat energy are more efficient ventilation and to lower the indoor temperature when away.

A majority of the respondents believe that those who have a higher temperature in the flat should pay more than those with lower temperatures, indicating a need for IMC. Something else that indicates a need or desire for some form of IMC is how the tenants' attitudes to IMC have changed over time. In case B, at the time of installation of the IMC system only 23 per cent were positive, but at the time of the survey the figure had increased to as high as 70 per cent. But while it was 70 per cent being positive it was only 47 per cent and 43 per cent (case A and B) respectively who believed the current IMC system was totally fair. So to get away from the annoyance with the IMC there is a need for the development of techniques to get a fairer system. Hypothetically, if there was an IMC system that was entirely fair that does not mean 
that it necessarily would be accepted by the tenants. However, it would probably be easier for landlords to justify why IMC is used.

For countries that have or had a high proportion of dwellings with individual heating IMC can be a great opportunity to lower energy costs. A boiler in each flat provides greater operating and maintenance costs than if the property has a central heating system. A conversion of a property from individual heating to central heating also opens the door to alternative heating methods that would otherwise not be possible in the individual flat. District heating is an environmentally friendly and energy efficient system as it is well-adapted as a central source of heat. The central heating system has the disadvantage of heating costs that are common and therefore must be divided between the flat owners respectively. A well-functioning IMC system may be the technical solution to the problem, but at the same time it also creates the problem that all concerned should understand and accept the system. In multi-dwelling housing with condominiums where each individual owner of a flat has to accept the change, the information provided is extremely important. With flat owners not understanding how IMC works or perceiving unfair treatment a system would be doomed to failure. Since flow measurement of heat has many similarities with individual heating, such an IMC system can possibly be justified to the flat owners at a conversion to central heating.

In England, the proportion of homes with central heating has increased from 31 per cent in 1970 to 91 per cent in 2006 (BRE, 2008, p. 38). The move to central heating has led to improved thermal comfort, which means higher indoor temperatures (BRE, 2008, p. 33). An increase in indoor temperature in turn results in higher energy use. To curb the increase in energy use, IMC can be a useful tool. Heating is centrally located but the charge for heat takes place individually just as before the conversion to central heating.

The ability to affect the costs of heat has led to every third tenant in the study having actively chosen to have a lower temperature indoors. This provides some support to previous studies that show a reduction in energy use with the IMC. But there is no correlation between having chosen a lower temperature and the attitude to IMC. Otherwise, a lower temperature might affect the attitude to IMC negatively.

\section{Conclusion}

Because installation and maintenance costs are important, projects are not necessarily profitable even if usage of energy is reduced. But a reduced energy use can be a good argument for individual metering and charging of heat. A landlord can be profiled as the owner of environment-friendly or low-impact housing. A large potential with IMC can be seen, reducing the use of energy and thus the impact on the environment as well as the individual's economy. But there is an annoyance among tenants with IMC. The annoyance is based on belief that IMC systems are unfair but also on lack of information. In order to increase the extension of IMC a better understanding of how IMC works and why the system exists is required. Information to the tenants needs to be improved and the technique should be developed for the system to be fairer and thus become more accepted by both landlords and tenants. A decision to install the IMC system is often made by the landlord and the tenant has in many cases simply to accept the change. Further research is needed on how factors like time or regulations can affect the perception of Individual Heat Metering and Charging. In Germany, where the individual heat measurements has been in existence for many years, fixed by
Individual heat metering

213 
SS

28,3

214

law since 1981, is the acceptance of IMC greater there? And which of the various IMC-techniques is more or less appropriate for different types of buildings?

\section{References}

Andersson, G. (2001), Kv Jankowitz - Individuell värmemätning och inverkan av värmeövergång mellan lägenheter, Bengt Dahlgren AB, Arbetsnummer, 50-8351101.

Berndtsson, L. (1999), Utredning angående erfarenheter av individuell mätning av värme och varmvatten i svenska Flerbostadshus, Swedish Energy Agency, Eskilstuna, ER24:1999.

Berndtsson, L. (2003), Individuell värmemätning $i$ svenska flerbostadshus - En lägesrapport, Swedish Energy Agency, Eskilstuna, project number, P11835-2.

Boligministeriet (1995), Betcenkning om obligatorisk individuel måling af forbrugsposter, Betænkning 1286, København.

BRE (2008), Domestic energy factfile 2008 - energy efficiency of the British housing stock, BRE, Watford.

Bundesministeriums der Justiz (1981), Verordnung über die verbrauchsabhängige Abrechnung der Heiz- und Warmwasserkosten, Budesministeriums de Justiz, Berlin.

Directive 2004/22/EC (2004), "Directive 2004/22/EC of the European Parliament and of the Council on measuring instruments", Official Journal of the European Union, 31 March 2004.

Directive 2006/32/EC (2006), "Directive 2006/32/EC of the European Parliament and of the Council on measuring instruments", Official Journal of the European Union, 5 April 2006.

Elforsk (2008), Energianvändning $i$ flerbostadshus och lokaler - Idag och i nära framtid, Report no. 08:32, April, Elforsk, Stockholm.

Henryson, J., Håkansson, T. and Pyrko, J. (2000), "Energy efficiency in buildings through information - Swedish perspective", Energy Policy, Vol. 28 No. 2000, pp. 169-80.

Jensen, L. (1999), Utvärdering av Hälsingborgshems system för komfortdebitering, Avdelningen för installationsteknik, Lunds Tekniska Högskola, Lund, Sweden.

JRC - Joint Research Centre (2008), European Commission.

Kenworthy, A.T. (1978), "Climatic exposure and fuel consumption in high rise dwellings", Building and Environment, Vol. 13 No. 3, pp. 167-74.

Layton, E. (1977), "Conditions of technological development", in Spiegel-Rosing, I. and de Sola Price, D. (Eds), Science, Technology and Society: A Cross-Disciplinary Perspective, Sage, Beverly Hills, CA, pp. 197-222.

(The) National Board of Housing, Building and Planning (2006), Individuell mätning av värmeförbrukningen $i$ flerbostadshus $i$ Tyskland, ISBN: 91-7147-945-7, Boverket, Karlskrona, Sweden.

(The) National Board of Housing, Building and Planning (2008), Individuell mätning och debitering $i$ flerbostadshus, ISBN: 978-91-86045-24-1, Boverket, Karlskrona, Sweden.

Schou, P. (1982), Tillämpad experimentell beteendeanalys vid energisparande, Stockholm University, Sweden, p. 57.

\section{Corresponding author}

Simon Siggelsten can be contacted at: Simon.Siggelsten@mah.se

To purchase reprints of this article please e-mail: reprints@emeraldinsight.com Or visit our web site for further details: www.emeraldinsight.com/reprints 